\title{
Estimating the CDOM absorption coefficient in tropical inland waters using OLI/Landsat-8 images
}

\author{
Enner Alcântara, Nariane Bernardo, Fernanda Watanabe, Thanan Rodrigues, \\ Luiz Rotta, Alisson Carmo, Milton Shimabukuro, Stela Gonçalves \& Nilton \\ Imai
}

To cite this article: Enner Alcântara, Nariane Bernardo, Fernanda Watanabe, Thanan Rodrigues, Luiz Rotta, Alisson Carmo, Milton Shimabukuro, Stela Gonçalves \& Nilton Imai (2016) Estimating the CDOM absorption coefficient in tropical inland waters using OLI/Landsat-8 images, Remote Sensing Letters, 7:7, 661-670, DOI: 10.1080/2150704X.2016.1177242

To link to this article: https://doi.org/10.1080/2150704X.2016.1177242

$$
\text { Published online: } 25 \text { Apr } 2016 .
$$

Submit your article to this journal ¿

Џlll Article views: 232

View Crossmark data ¿

Citing articles: 9 View citing articles 4 


\title{
Estimating the CDOM absorption coefficient in tropical inland waters using OLI/Landsat-8 images
}

\author{
Enner Alcântara (10 ${ }^{a}$, Nariane Bernardo ${ }^{a}$, Fernanda Watanabe ${ }^{a}$, Thanan Rodrigues ${ }^{a}$, \\ Luiz Rotta ${ }^{a}$, Alisson Carmo ${ }^{a}$, Milton Shimabukuro ${ }^{b}$, Stela Gonçalves ${ }^{a}$ and Nilton Imai ${ }^{a}$ \\ ${ }^{a}$ Department of Cartography, São Paulo State University - Unesp, Presidente Prudente, Brazil; ${ }^{b}$ Department \\ of Mathematics and Computer Science, São Paulo State University - Unesp, Presidente Prudente, Brazil
}

\begin{abstract}
Coloured dissolved organic matter (CDOM) is the most abundant dissolved organic matter (DOM) in many natural waters and can affect the water quality, such as the light penetration and the thermal properties of water system. So the objective of this letter was to estimate the CDOM absorption coefficient at $440 \mathrm{~nm}$, $a_{\mathrm{CDOM}}(440)$, in Barra Bonita Reservoir (São Paulo State, Brazil) using operational land imager (OLI)/Landsat-8 images. For this two field campaigns were conducted in May and October 2014. During the field campaigns remote sensing reflectance $\left(R_{\mathrm{rs}}\right)$ were measured using a TriOS hyperspectral radiometer. Water samples were collected and analysed to obtain the $a_{\mathrm{CDOM}}(440)$. To predict the $a_{\mathrm{CDOM}}(440)$ from $R_{\mathrm{rs}}$ at two key wavelengths (650 and $480 \mathrm{~nm}$ ) were regressed against laboratory-derived $a_{\mathrm{CDOM}}(440)$ values. The validation using in situ data of $a_{\mathrm{CDOM}}(440)$ algorithm indicated a goodness of fit, $R^{2}=0.70$, with a root mean square error (RMSE) of $10.65 \%$. The developed algorithm was applied to the OLI/Lansat-8 images. Distribution maps were created with OLI/Landsat-8 images based on the adjusted algorithm.
\end{abstract}

ARTICLE HISTORY

Received 18 January 2016

Accepted 1 April 2016

\section{Introduction}

Coloured dissolved organic matter (CDOM) is a photoactive component of dissolved organic carbon (DOC) and is often viewed as a reliable tracer of DOC (Zhu et al. 2014). According to Hoge and Lyon (2002) in freshwater environments the optical properties of CDOM-laden water are affected by microbiological assemblages and suspended substances. CDOM absorptivity in these aquatic systems can be quite high with absorption as high as $20 \mathrm{~m}^{-1}$ at $440 \mathrm{~nm}$ (Brezonik, Menken, and Bauer 2005).

Remote sensing provides an effective approach to estimate the CDOM absorption coefficient $\left(a_{\mathrm{CDOM}}\right)$ in a large spatial scope. The estimation of $a_{\mathrm{CDOM}}$ via remote sensing could be a valuable tool for studying ecological changes as well as carbon cycling at global scales (Tranvik et al. 2009). Bowers et al. (2000) theorized that $a_{\mathrm{CDOM}}$ at $440 \mathrm{~nm}$ $\left(a_{\mathrm{CDOM}}(440)\right)$ could be derived from satellite spectral data by ratio of reflectances in the red and another part of the spectrum. Binding and Bowers (2003) showed that $a_{\mathrm{CDOM}}$ 
(440) could be derived using the ratio of remotely sensed reflectances $\left(R_{\mathrm{rs}}\right)$ in the red and blue-green parts of the spectrum $\left(R_{\mathrm{rs}} 665 / R_{\mathrm{rs}} 490\right)$.

The algorithms developed for case 1 waters may not be accurate for inland case 2 water, because of potential interference from solutes and suspended matter found in such waters that are not typically found in open oceans. A summary of bio-optical models often used to estimate the $a_{\mathrm{CDOM}}$ can be accessed in Zhu et al. (2014) and the factors that affect the measurement of CDOM from remote sensing are in Brezonik et al. (2015).

Then the scientific question of this letter is that: the potential of the spectral band ratio (red/blue-green) to estimate $a_{\mathrm{CDOM}}(440)$ holds true if we are working with tropical inland case 2 waters? To address this issue, the aim of this letter was to estimate the $a_{\mathrm{CDOM}}(440)$ using the red/blue-green band ratio. For this two field trips were conducted to measure the $R_{\mathrm{rs}}$ and to collect water samples to obtain the $a_{\mathrm{CDOM}}(440)$ in laboratory. A model was developed and then applied in operational land imager (OLI)/Landsat-8 images to show the $a_{\mathrm{CDOM}}(440)$ distribution. Hence to our knowledge it is the first time that this type of research was conducted to study the $a_{\mathrm{CDOM}}(440)$ distribution in tropical inland waters in Brazil.

\section{Materials and methods}

\subsection{Study area}

Barra Bonita hydroelectric reservoir (BBHR) $\left(22^{\circ} 31^{\prime} 10^{\prime \prime} \mathrm{S}\right.$ and $48^{\circ} 32^{\prime} 3^{\prime \prime} \mathrm{W}$ ) lies in the middle course of the Tietê River, São Paulo State, Brazil (Figure 1). The BBHR is situated in a transitional region between tropical and subtropical climate, characterized by a dry period (May-October) and a wet period (November-April). The maximum depth is $25 \mathrm{~m}$, with an average of $10.2 \mathrm{~m}$. The water retention time varies from 30 days (austral summer) to 180 days (austral winter), while the flow range is of $1,500 \mathrm{~m}^{3} \mathrm{~s}^{-1}$ in the austral summer (wet season) to $200 \mathrm{~m}^{3} \mathrm{~s}^{-1}$ in the austral winter (dry season, Tundisi, Matsumura-Tundisi, and Abe 2008). BBHR is characterized as highly productive water and presents a species richness and high concentration of phytoplankton (DellamanoOliveira et al. 2008). The BBHR is eutrophic due to a high load of wastewater and fertilizers coming from the lower Tietê River.

\subsection{Fieldwork}

Two campaigns were carried out from 5 to 8 May 2014 and from 13 to 17 October 2014.

\subsection{Radiometric data}

In situ radiometric measurements were made using three TriOS hyperspectral radiometers: two ARC-VIS sensors with a $7^{\circ}$ field-of-view in order to measure radiance, and one ACC-VIS sensor with a cosine collector to measure irradiance. Both ARC and ACC sensors have $3.3 \mathrm{~nm}$ of spectral sampling, work in a wavelength ranging from $320 \mathrm{~nm}$ to $950 \mathrm{~nm}$, use an integration time of $4 \mathrm{~ms}-8 \mathrm{~s}$, and an operation temperature ranging from $-10^{\circ} \mathrm{C}$ to $+50^{\circ} \mathrm{C}$ (TriOS, Oldenburg, Germany). Radiances (total radiance $-L_{t}$; and 

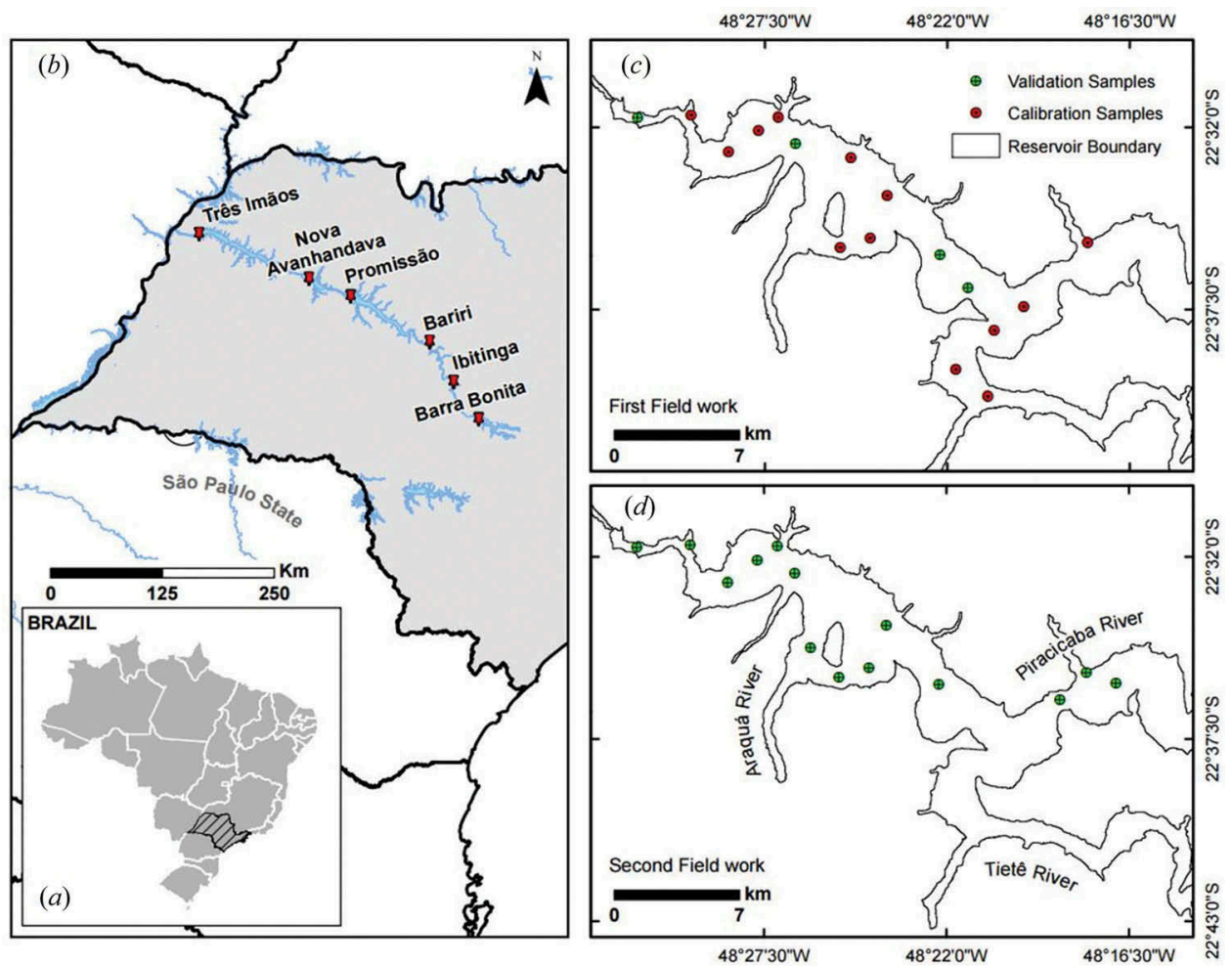

Figure 1. Location of the study area (a) Brazil, with São Paulo State highlighted, (b) Tietê River and the cascade of reservoirs (from upstream to downstream: Barra Bonita, Ibitinga, Bariri, Promissão, Nova Avanhandava, and Três Irmãos) and the sampling locations from the first,(c) and the second, (d) fieldwork.

diffuse radiance $-L_{\text {sky, }}$, both in $\left.\mathrm{W} \mathrm{m}^{-2} \mathrm{sr}^{-1}\right)$ and downwelling irradiance data $\left(E_{\mathrm{d}}\left(0^{+}\right)\right.$, in

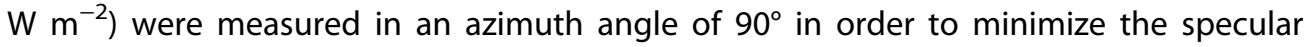
reflection (Mobley 1999). To avoid shadow from the instrument the fieldwork followed the geometry suggested by Mueller (2003). The hyperspectral measurements allowed the computing of the $R_{\mathrm{rs}}$ (units in $\mathrm{sr}^{-1}$ ) above water, by using Equation (1).

$$
R_{\mathrm{rs}}\left(\theta, \phi, \lambda, 0^{+}\right)=\frac{L_{\mathrm{t}}\left(\theta, \phi, \lambda, 0^{+}\right)-0.028 \times L_{\mathrm{sky}}\left(\theta, \phi, \lambda, 0^{+}\right)}{E_{\mathrm{d}}\left(\theta, \phi, \lambda, 0^{+}\right)}
$$

where $\theta$ is the azimuthal angle (in degrees), $\phi$ is the zenithal angle (in degrees), $\lambda$ is the wavelength (in $\mathrm{nm}$ ), and $\mathrm{O}^{+}$indicates that measurements were made just above the water surface.

To simulate the $R_{\mathrm{rs}}(\lambda)$ signals that would be recorded by the satellite sensor at each channel centred at wavelength $\lambda$, weighted averages of each $R_{\mathrm{rs}}$ spectrum were calculated by using as weights the spectral band responses of OLI (Barsi et al. 2014), as given below (Equation 2).

$$
R_{\mathrm{r} \__{-} \mathrm{S}}(\lambda)=\frac{\sum_{\lambda} R_{\mathrm{rs}}(\lambda) \times S(\lambda)}{\sum_{\lambda} S(\lambda)}
$$


where $S(\lambda)$ is the OLI spectral response function, and $R_{\mathrm{rs}_{-} \mathrm{s}}(\lambda)$ is the simulated $R_{\mathrm{rs}}$. The OLI bands simulated were band $4(640-670 \mathrm{~nm})$ and $2(450-510 \mathrm{~nm})$.

\subsection{Coloured dissolved organic matter absorption coefficient ( $\left.a_{C D O M}\right)$}

Water samples were filtered through a nylon membrane Whatman with $0.22 \mu \mathrm{m}$ pore size and $47 \mathrm{~mm}$ diameter to measure the CDOM absorbance $\left(A_{\mathrm{CDOM}}\right)$. The filtrates were stored and kept cool in the dark until the analysis. The samples were measured at room temperature using a quartz cuvette with $10 \mathrm{~cm}$ optical path. The measurements were conducted in a spectral range of $280-800 \mathrm{~nm}$ using a 2600 UV-Vis spectrophotometer (Shimadzu, Kyoto, Japan) with a single beam and Milli-Q water was used as blank reference. From the $A_{\mathrm{CDOM}}, a_{\mathrm{CDOM}}$ was calculated by using Equation (3) (Briucaud, Morel, and Prieur 1981).

$$
a_{\mathrm{CDOM}}=2.3 \frac{A_{\mathrm{CDOM}}(\lambda)}{l},
$$

where $A_{\mathrm{CDOM}}(\lambda)$ is the absorbance at wavelength $(\lambda)$ and $/$ is the cuvette path length in metres (Briucaud, Morel, and Prieur 1981).

\section{5. $a_{\text {СDOM}}(440)$ algorithm development}

Based on Binding and Bowers (2003), the $a_{\mathrm{CDOM}}(440)$ model was derived for red/bluegreen ratio, adapting the $R_{r s}$ for OLI/Landsat- 8 bands. To fit the model, a regression analysis of $R_{\mathrm{rs}}$ ratio, at $650 \mathrm{~nm}$ (OLI band 4) and $480 \mathrm{~nm}$ (OLI band 2) $\left(R_{\mathrm{rs}}(650) / R_{\mathrm{rs}}(480)\right.$ ), against $a_{\mathrm{CDOM}}(440)$ measured in laboratory was carried out to predict the last from OLI/ Landsat- 8 images. This band ratio was chosen because these bands are free from atmospheric correction errors (Belanger et al. 2008).

\subsection{OLI/ Landsat-8 images processing}

The developed algorithm to predict the $a_{\mathrm{CDOM}}(440)$ was applied on five OLI/Landsat-8 images (path/row 220/76) from 2014 (level 1 product). The images were acquired on 31 January, 11 September, 13 October, 29 October, and 16 December and available on United States Geological Survey (USGS) site (www.earthexplorer.com). The signal registered by a remote sensor is influenced by the atmospheric attenuation (scattering and absorption of gases and molecules), and it is affected by the differences in geometry and illumination conditions. Then, it is essential to differentiate these interferences from the real radiometric signal from the targets. Based on this, the radiometric normalization process was conducted using the iteratively reweighted multivariate alteration detection - IR-MAD (Canty, Nielsen, and Schmidt 2004).

To conduct the IR-MAD processing, the reference image was atmospherically corrected by using Fast Line-of-sight Atmospheric Analysis of Hypercubes (FLAASH, AdlerGolden et al. 1999) method. The reference OLI image was acquired by OLI on 26 October 2013, and was chosen for being the oldest image from the OLI time series without cloud coverage. The OLI images were converted into top-of-atmosphere radiance $\left(L_{\text {TOA }}\right)$ using the conversion factors available in the metadata file of each image. The reference image 
in surface reflectance $\left(R_{\text {SURF }}\right)$ and the $L_{\text {TOA }}$ images were used as input in IR-MAD. As result, the 2014 images were converted into $R_{\mathrm{SURF}}$. To apply the $a_{\mathrm{CDOM}}(440)$ algorithm, the $R_{\text {SURF }}$ of each image was divided by $\pi$ to convert them into $R_{\mathrm{rs}}$ (Moses et al. 2012). The closure between the $R_{\mathrm{rs}}$ obtained from the OLI images and from the in situ $R_{\mathrm{rs}}$ can be accessed in Watanabe et al. (2015).

\section{Results and discussion}

\subsection{Average $a_{C D O M}$ measured in situ}

The average $a_{\mathrm{CDOM}}$ spectra showed the characteristic exponential decay of absorption with increasing wavelength (Briucaud, Morel, and Prieur 1981), which can be represented by the following equation:

$$
a_{\mathrm{y}}=a_{\mathrm{CDOM}} 440 \times e^{(-m(\lambda-440))},
$$

where $a_{\mathrm{y}}$ is the absorption by CDOM at wavelength $\lambda$, and $m$ is a constant slope parameter which represents the rate of decay of absorption with $\lambda$. The average $a_{\mathrm{CDOM}}$ spectra for each field survey (May and October 2014) are shown in Figure 2. Descriptive statistics can be accessed in Watanabe et al. (2015).

The average $a_{\mathrm{CDOM}}(440)$ for May and October was of 0.787 (ranging from 0.644 to 1.112 ) and $1.110 \mathrm{~m}^{-1}$ (ranging from 0.811 to 1.413 ) and the slope parameter $m$ was of 0.012 and $0.014 \mathrm{~nm}^{-1}$, respectively. There is more CDOM absorptivity in October than in May. This occurs because October is the end of the dry season and the beginning of the wet season; therefore the rain on the watershed carries organic matter (mainly from agriculture and wastewater) into the Barra Bonita (BB) reservoir. The temporal modifications in the slope parameter can be observed when CDOM is generated by bacteria (Yamashita et al. 2013). According to Organelli et al. (2014), the solar radiation in surface waters degrades the CDOM molecules and yields high slope parameter and low $a_{\mathrm{CDOM}}$ values. To investigate the spatial distribution of $a_{\mathrm{CDOM}}(440)$ an $R_{\mathrm{rs}}$-based algorithm was developed.

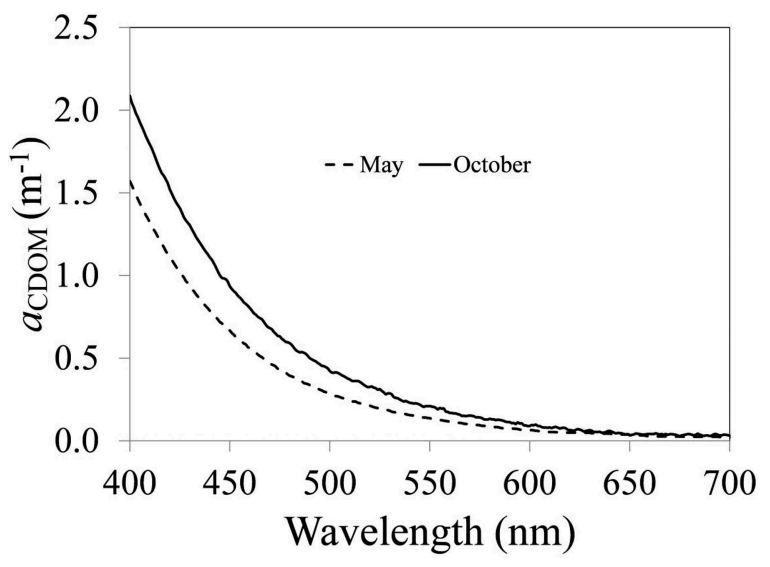

Figure 2. Average $a_{\mathrm{CDOM}}$ measured in laboratory from water samples collected in fieldworks in May and October 2014. 


\subsection{CDOM absorption algorithm}

To predict the $a_{\mathrm{CDOM}}(440)$ from $R_{\mathrm{rs}}$ a band ratio using two key wavelengths (650 and $480 \mathrm{~nm}$ ) was adopted and regressed against laboratory derived $a_{\mathrm{CDOM}}(440)$ values (Figure 3(a)). Several band ratios were tested and the best fit was obtained using the mentioned ratio. Using $a_{\mathrm{CDOM}}(440)$ and concurrently acquired in situ spectral data from $\mathrm{BB}$ reservoir, the following equation was derived:

$$
a_{\mathrm{CDOM}}(440)=2.70 \times\left(\frac{R_{\mathrm{rs}}(650)}{R_{\mathrm{rs}}(480)}\right)^{2}-6.14 \times \frac{R_{\mathrm{rs}}(650)}{R_{\mathrm{rs}}(480)}+4.19
$$

The validation of the Equation (5) indicated a goodness of fit, $R^{2}=0.70$, between measured $a_{\mathrm{CDOM}}(440)$ and those predicted by the algorithm (Figure $3(\mathrm{~b})$ ). The obtained root mean square error (RMSE) was of $10.65 \%$ (mean bias of $-0.037 \mathrm{~m}^{-1}$ ) and for $a_{\mathrm{CDOM}}$ (440) values lower than $0.85 \mathrm{~m}^{-1}$ the algorithm overestimated and for $a_{\mathrm{CDOM}}(440)$ values higher than $0.85 \mathrm{~m}^{-1}$ the model underestimated. The Equation (5) was applied to the OLI/Landsat-8 images to obtain the $a_{\mathrm{CDOM}}(440)$ distribution.

\subsection{Application of the $a_{\mathrm{CDOM}}(440)$ algorithm to OLI/Landsat-8 images}

The predicted $a_{\mathrm{CDOM}}(440)$ distributions based on OLI/Landsat-8 images are presented in Figure 4. Overall, the highest $a_{\mathrm{CDOM}}(440)$ values occur in Tietê River during the dry season (Figure 4(a)) and in Piracicaba River during the wet season (Figure 4(b) and (d)). The exception of this rule are the results presented in Figure 4(c) and (e), where no rain occurred in the week of the image date; and in these cases the highest $a_{\mathrm{CDOM}}(440)$ values come from the Tietê River. In addition, high $a_{\mathrm{CDOM}}(440)$ values are more often found in the south-west portion of the BB reservoir.

This is a result of the wind preferential direction that stacks water from northeast to south-west portion. According to Barbosa et al. (1999), BB reservoir is a polymictic ecosystem with fluctuations promoted by rainfall and wind. External forces such as, wind, intrusion of water from tributaries, low retention time during Austral summer months (December-March), and density currents as a result of the contribution of the two main tributaries Tietê and Piracicaba Rivers, may influence the mixing processes in the horizontal and vertical scales in this reservoir. Values higher than $1.10 \mathrm{~m}^{-1}$ contains more uncertainty due to the dataset range used to calibrate the model (see Figure 3(a)).
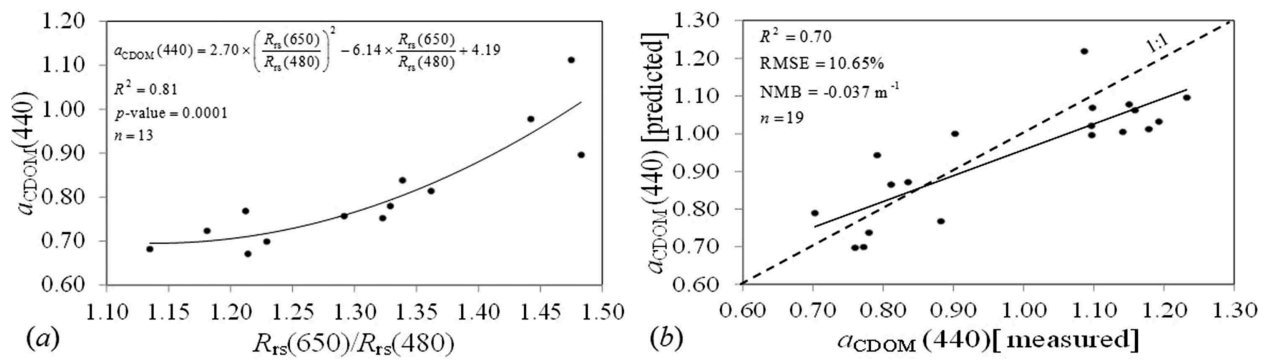

Figure 3. Fitted $a_{\mathrm{CDOM}}$ model using the calibration dataset (a) and the model validation, and (b) $\mathrm{RMSE}=$ root mean square error and $\mathrm{NMB}=$ normalized mean bias. 


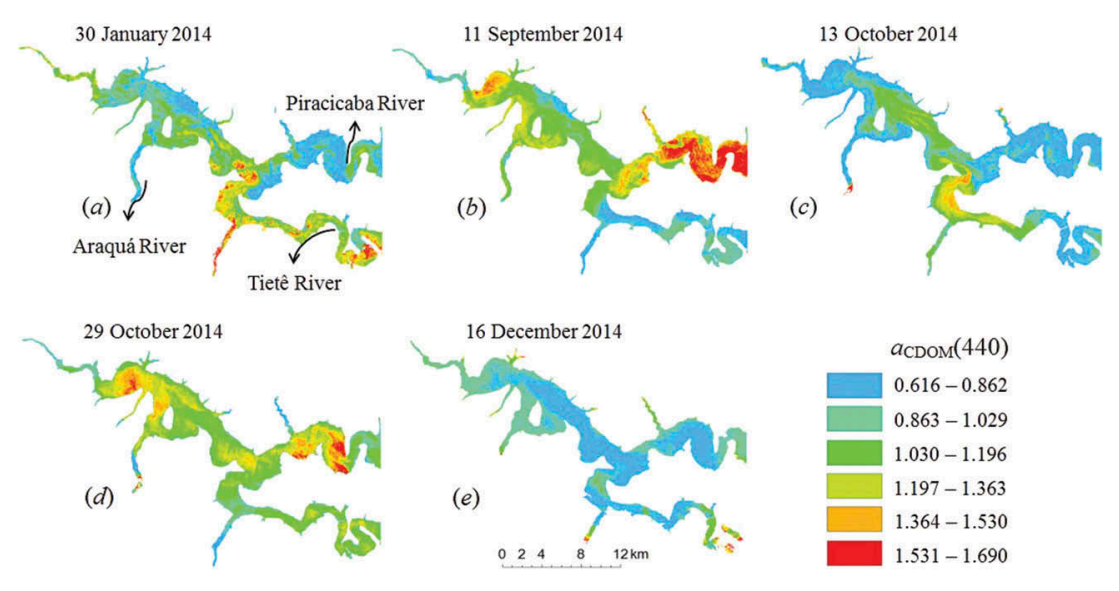

Figure 4. Spatial distribution of $a_{\mathrm{CDOM}}(440)$ in BB reservoir: (a) 30 January 2014, (b) 11 September 2014, (c) 13 October 2014, (d) 29 October 2014, and (e) 16 December 2014.
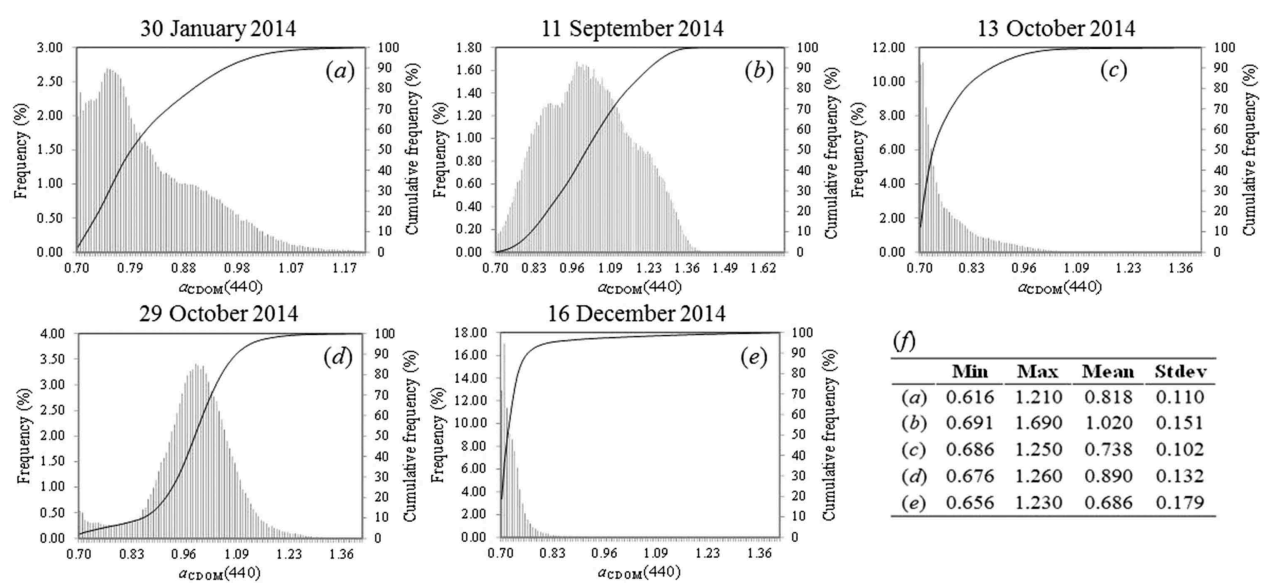

Figure 5. Frequency of occurrence of different values of $a_{\mathrm{CDOM}}(440)$ for (a) 30 January 2014, (b) 11 September 2014, (c) 13 October 2014, (d) 29 October 2014, and (e) 16 December 2014 and the descriptive statistics, minimum, maximum, mean, and standard deviation (Stdev) for each month (f).

The spatial distribution of $a_{\mathrm{CDOM}}(440)$ can be summarized using frequency histograms (Figure 5). The frequency histogram for $a_{\mathrm{CDOM}}(440)$ predicted on 30 January 2014 shows that values lower than $0.79 \mathrm{~m}^{-1}$ are more frequent and represent approximately $55 \%$ of all the pixels (Figure 5(a)).

For 11 September 2014, the $a_{\mathrm{CDOM}}(440)$ histogram exhibited a normal distribution, with frequency values between 0.96 and $1.09 \mathrm{~m}^{-1}$, representing $70 \%$ of the pixels (Figure $5(\mathrm{~b})$ ). For the $a_{\mathrm{CDOM}}(440)$ predicted in October the histogram was very different, since the lowest values (lower than $0.75 \mathrm{~m}^{-1}$ ) were more frequent (65\%) in the image from 13 October; on the other hand the $a_{\mathrm{CDOM}}(440)$ values were more normally distributed between 0.83 and $1.15 \mathrm{~m}^{-1}$ for the image from 29 October. The histogram from 16 December 2014 (Figure 5(e)) the more frequent $a_{\mathrm{CDOM}}(440)$ values were lower than $0.75 \mathrm{~m}^{-1}$. 
The descriptive statistics for the predicted $a_{\mathrm{CDOM}}(440)$ values are shown in Figure 5(f). The highest $a_{\mathrm{CDOM}}(440)$ was found in the image from September and the lowest from January. The highest standard deviation was found in December and the lowest in October 11. The highest mean $a_{\mathrm{CDOM}}(440)$ was found in September as a result of the discharge of water from Piracicaba River.

Using OLI/Landsat-8 images to predict the chlorophyll-a (Chl-a) concentration in BB reservoir, Watanabe et al. (2015) found that the Piracicaba and Tietê Rivers were classified as hypertrophic both in May and in October. The Chl-a concentration in these months reached up to $500 \mathrm{mg} \mathrm{m}^{-3}$. These authors also reported that in January the Chl- $a$ concentration was higher in Tietê River than in Piracicaba River and the opposite occurred in October 2014. Since the phytoplankton degradation is one source of CDOM and DOC the knowledge about the Chl- $a$ concentration distribution is essential.

Another source of CDOM and DOC is the surrounding terrestrial ecosystem. Prado and Novo (2015) used TM/Landsat-5 images to classify the land use and land cover in the Barra Bonita watershed in the year of 2002. The results of this classification showed that the watershed was mainly occupied by pasture $(29.35 \%)$, sugar cane $(28.06 \%)$, natural vegetation (15.21\%), bare soil (10.30\%), and urban area $(7.34 \%)$. There is a tendency in increasing the agriculture area in the watershed and therefore the CDOM and DOC will also increase. Since DOC has significant implications on our environment and climate change due to its importance role in the carbon cycle, studying the CDOM distribution in aquatic systems will greatly improve our understanding about the dynamics of DOC and the impact on water quality (Tranvik et al. 2009).

\section{Conclusion}

In this letter the in situ measurements, satellite images and algorithm development have been focused on inland water, where biogeochemical and bio-optical characteristics are more complex than those in marine waters. The band ratio, $R_{\mathrm{rs}} 650 / R_{\mathrm{rs}} 480$, was capable to estimate the $a_{\mathrm{CDOM}}(440)$ from OLI/Landsat-8 images. Even without specific bands for CDOM application, OLI/Landsat-8 images exhibited sensibility and potential for estimating $a_{\mathrm{CDOM}}(440)$. The $a_{\mathrm{CDOM}}(440)$ distribution showed the influence of rain season on the contribution from Tietê and Piracicaba River along the year. The land use and land cover in the watershed also contributes to increase the $a_{\mathrm{CDOM}}(440)$ values, especially during the rainy season. Due to their empirical base, this algorithm may be specific for BB reservoir and future research is needed to confirm if this model can be used in other reservoirs.

\section{Disclosure statement}

No potential conflict of interest was reported by the authors.

\section{Funding}

This study was supported by São Paulo Research Foundation - FAPESP [Project number: 2012/ 19821-1] and National Counsel of Technological and Scientific Development - CNPq [Projects numbers: 400881/2013-6 and 472131/2012-5]. 


\section{References}

Adler-Golden, S. M., M. W. Matthew, L. S. Bernstein, R. Y. Levine, A. Berk, S. C. Richtsmeier, P. K. Acharya, et al. 1999. "Atmospheric Correction for Shortwave Spectral Imagery Based on MODTRAN4." SPIE Proceedings, Imaging Spectrometry 3753: 61-69. doi:10.1117/12.366315.

Barbosa, F. A. R., J. Padisák, E. L. G. Espíndola, G. Borics, and O. Rocha. 1999. "The Cascading Reservoir Continuum Concept (CRCC) and Its Application to the River Tietê-Basin, São Paulo State, Brazil." In Theoretical Reservoir Ecology and Its Applications, edited by J. G. Tundisi, and M. Straskraba, 425-437. São Carlos: International Institute of Ecology, Academy of Sciences and Backhuys Publishers.

Barsi, J., K. Lee, G. Kvaran, B. Markham, and J. Pedelty. 2014. "The Spectral Response of the Landsat8 Operational Land Imager." Remote Sensing 6 (10): 10232-10251. doi:10.3390/rs61010232.

Belanger, S., M. Babin, and P. Larouche. 2008. "An Empirical Ocean Color Algorithm for Estimating the Contribution of Chromophoric Dissolved Organic Matter to Total Light Absorption in Optically Complex Waters." Journal of Geophysical Research 113: C04027. doi:10.1029/ 2007JC004436.

Binding, C. E., and D. G. Bowers. 2003. "Measuring the Salinity of the Clyde Sea from Remotely Sensed Ocean Colour." Estuarine, Coastal and Shelf Science 57: 605-611. doi:10.1016/S0272-7714 (02)00399-2.

Bowers, D. G., G. E. L. Harker, P. S. D. Smith, and P. Tett. 2000. "Optical Properties of a Region of Freshwater Influence (The Clyde Sea)." Estuarine, Coastal and Shelf Science 50: 717-726. doi:10.1006/ecss.1999.0600.

Brezonik, P., K. D. Menken, and M. Bauer. 2005. "Landsat-Based Remote Sensing of Lake Water Quality Characteristics, Including Chlorophyll and Colored Dissolved Organic Matter (CDOM)." Lake and Reservoir Management 21: 373-382. doi:10.1080/07438140509354442.

Brezonik, P., L. G. Olmanson, J. C. Finlay, and M. E. Bauer. 2015. "Factors Affecting the Measurement of CDOM by Remote Sensing of Optically Complex Inland Waters." Remote Sensing of Environment 157: 199-215. doi:10.1016/j.rse.2014.04.033.

Briucaud, A., A. Morel, and L. Prieur. 1981. "Absorption by Dissolved Organic Matter of the Sea (Yellow Substance) in the UV and Visible Domains." Limnology and Oceanography 26: 43-53. doi:10.4319/lo.1981.26.1.0043.

Canty, M. J., A. A. Nielsen, and M. Schmidt. 2004. "Automatic Radiometric Normalization of Multitemporal Satellite Imagery." Remote Sensing of Environment 91: 441-451. doi:10.1016/j. rse.2003.10.024.

Dellamano-Oliveira, M. J., A. A. H. Vieira, O. Rocha, V. Colombo, and C. L. Sant'Anna. 2008. "Phytoplankton Taxonomic Composition and Temporal Changes in a Tropical Reservoir." Fundamental and Applied Limnology 171: 27-38. doi:10.1127/1863-9135/2008/0171-0027.

Hoge, F. E., and P. E. Lyon. 2002. "Satellite Observation of Chromophoric Dissolved Organic Matter (CDOM) Variability in the Wake of Hurricanes and Typhoons." Geophysical Research Letters 29: 14-1-14-4. doi:10.1029/2002GL015114.

Mobley, C. D. 1999. "Estimation of the Remote-Sensing Reflectance from Above-Surface Measurements." Applied Optics 38 (36): 7442-7455. doi:10.1364/AO.38007442.

Moses, W. J., A. A. Gitelson, R. L. Perk, D. Gurlin, D. C. Rundquist, B. C. Leavitt, T. M. Barrow, and P. Brakhage. 2012. "Estimation of Chlorophyll-A Concentration in Turbid Productive Waters Using Airborne Hyperspectral Data." Water Research 46 (4): 993-1004. doi:10.1016/j. watres.2011.11.068.

Mueller, J. L. 2003. "In-Water Radiometric Profile Measurements and Data Analysis Protocols." In Ocean Optics Protocols for Satellite Ocean Color Sensor Validation, Revision 4, Volume III: Radiometric Measurements and Data Analysis Protocols, edited by J. L. Mueller, G. S. Fargion, 
and C. R. McClain, 7-20. Greenbelt, MD: NASA Goddard Space Flight Space Center, NASA/TM2003-21621/Rev-Vol. III.

Organelli, E., A. Bricaud, D. Antoine, and A. Matsuoka. 2014. "Seasonal Dynamics of Light Absorption by Chromophoric Dissolved Organic Matter (CDOM) in the NW Mediterranean Sea (BOUSSOLE Site)." Deep Sea Research Part I: Oceanographic Research Papers 91: 72-85. doi:10.1016/j.dsr.2014.05.003.

Prado, R. B., and E. M. L. M. Novo. 2015. "Modeling Pollution Potential Input from the Drainage Basin into Barra Bonita Reservoir, São Paulo - Brazil." Brazilian Journal of Biology 75: 314-323. doi:10.1590/1519-6984.12013.

Tranvik, L. J., J. A. Downing, J. B. Cotner, S. A. Loiselle, R. G. Striegl, T. J. Ballatore, P. Dillon, K. Finlay, K. Fortino, and L. B. Knoll. 2009. "Lakes and Reservoirs as Regulators of Carbon Cycling and Climate." Limnology and Oceanography 54: 2298-2314. doi:10.4319/lo.2009.54.6_part_2.2298.

Tundisi, J. G., T. Matsumura-Tundisi, and D. S. Abe. 2008. "The Ecological Dynamics of Barra Bonita (Tietê River, SP, Brazil) Reservoir: Implications for Its Biodiversity." Brazilian Journal of Biology 68: 1079-1098. doi:10.1590/S1519-69842008000500015.

Watanabe, F., E. H. Alcântara, T. Rodrigues, N. N. Imai, C. Barbosa, and L. Rotta. 2015. "Estimation of Chlorophyll-a Concentration and the Trophic State of the Barra Bonita Hydroelectric Reservoir Using OLI/Landsat-8 Images." International Journal of Environmental Research and Public Health 12: 10391-10417. doi:10.3390/ijerph120910391.

Yamashita, Y., Y. Nosaka, K. Suzuki, H. Ogawa, K. Takahashi, and H. Saito. 2013. "Photobleaching as a Factor Controlling Spectral Characteristics of Chromophoric Dissolved Organic Matter in Open Ocean." Biogeosciences 10 (11): 7207-7217. doi:10.5194/bg-10-7207-2013.

Zhu, W., Q. Yu, Y. Q. Tian, B. L. Becker, T. Zheng, and H. J. Carrick. 2014. "An Assessment of Remote Sensing Algorithms for Colored Dissolved Organic Matter in Complex Freshwater Environments." Remote Sensing of Environment 140: 766-778. doi:10.1016/j.rse.2013.10.015. 